\title{
EFEKTIFITAS PELATIHAN PEMANFAATAN MEDIA BAHAN BEKAS KARDUS UNTUK PENINGKATAN KREATIVITAS GURU RA KECAMATAN CIPANAS CIANJUR
}

\author{
Ai Aisah \\ Alumni Magister Pendidikan Islam Konsentrasi PAUD Pascasarjana Unisba \\ (Kepala Raudhatul Athfal (RA) Terpadu Al-Barokah Cipanas) \\ e-mail : aitiabusana@gmail.com
}

\begin{abstract}
Abstrak. Berdasarkan pengamatan terhadap guru-guru RA Kecamatan Cipanas Kabupaten Cianjur, menunjukan guru-guru RA belum kreatif dalam memanfaatkan media bahan bekas kardus, sehingga berdampak kepada kurangnya partisipasi siswa dan proses pembelajaran. Pelatihan pemanfaatan media bahan bekas kardus, oleh instruktur dilaksanakan untuk menjawab tantangan, kebutuhan guru dalam meningkatkan kreativitas guru, dalam membuat media bahan bekas kardus. Penulis bermaksud menguji efektifitas pelatihan pemanfaatan media bahan bekas kardus untuk peningkatan kreativitas guru RA Kecamatan Cipanas Cianjur. Tujuan penelitian ini untuk memperoleh gambaran tentang efektifitas pelatihan pemanfaatan media bahan bekas kardus untuk peningkatan kreativitas guru, partisipasi siswa, dan proses pembelajaran, RA Kecamatan Cipanas Cianjur. Metode penelitian yang digunakan adalah metode deskriptif, dengan instrumen penelitian menggunakan wawancara dan kuesioner/angket yang disebarkan kepada 50 orang guru RA Kecamatan Cipanas Cianjur yang mengikuti pelatihan, dan telah melaksanakan pembelajaran. Teknik kategori dengan terlebih dahulu mencari rata-rata yaitu: Jika nilai $\geq$ rata-rata 0,5 dinyatakan ya atau mampu, Jika nilai $\leq$ ratarata 0,5 dinyatakan tidak/belum mampu. Hasil penelitian menyimpulkan (1) sebagian besar guru RA memahami materi pelatihan pemanfaatan media bahan bekas kardus, (2) sebagian besar guru-guru terdapat peningkatan kreativitas dalam memanfaatkan media bahan bekas kardus, (3) setelah mengikuti pelatihan berdampak pada peningkatan partisipasi siswa, (4) pelatihan tersebut menunjukkan adanya peningkatan terhadap proses pembelajaran.

Hasil penelitian ini berimplikasi pada (1) guru dapat memanfaatkan pelatihan untuk meningkatkan kreativitas, (2) guru dapat memanfaatkan media bahan bekas kardus untuk peningkatan proses pembelajaran.
\end{abstract}

\section{Kata Kunci : Kreativitas, kardus bekas, pelatihan.}

\begin{abstract}
Based on observations of teachers RA District of Cipanas Cianjur, showing teachers RA have not been creative in using media scrap materials cardboard, so the impact to the lack of participation of students and the learning process. Training of media use cardboard scrap materials, by instructors conducted to answer the challenges, the need for teachers to improve their creativity in making media cardboard scrap materials. The author intends to test the effectiveness of the training of media use cardboard scrap materials to increase their creativity RA District of Cipanas, Cianjur. The purpose of this study to gain an overview of the effectiveness of the training of media use cardboard scrap materials to increase the creativity of teachers, student participation and learning process, RA District of Cipanas, Cianjur. The method used is descriptive method, the research instrument using interviews and questionnaires / questionnaire distributed to 50 teachers RA Cipanas Cianjur District of training, and has been implementing the learning. Mechanical category by first finding the average, namely: If the average value $\geq 0.5$ expressed yes or capable, If the average value $\leq 0.5$ otherwise not / have not been able to The study concluded (1) the majority of teachers $R A$ understand training materials media use scrap materials cardboard, (2) the majority of teachers are enhancing creativity in utilizing the media scrap materials cardboard, (3) after training impact on increasing student participation, (4) the training showed an increase to the learning process. The results of this study have implications for (1) the teacher can utilize the training to enhance creativity, (2) the teacher can utilize scrap materials cardboard media for the improvement of the learning process.
\end{abstract}

Keywords: Creativity, Ussed cardboard, training.

\section{Pendahuluan}

Pendidikan anak usia dini (Paud), berperan penting dalam menyiapkan sumber daya manusia berkualitas Indonesia. Sumber daya manusia berkualitas sangat dibutuhkan, terutama saat memasuki era globalisasi dan perdagangan bebas, yang melahirkan persaingan ketat antar bangsa dan negara di dunia. Termasuk yang terjadi saat ini, yaitu Masyarakat Ekonomi ASEAN (MEA). 
Dalam UU Sisdiknas nomor 20 tahun 2003, disebutkan bahwa pendidikan anak usia dini adalah upaya yang ditujukan bagi anak sejak lahir sampai enam tahun, yang dilakukan melalui rangsangan pendidikan, untuk membantu pertumbuhan dan perkembangan jasmani dan rohani, agar anak memiliki kesiapan memasuki pendidikan selanjutnya. Dalam pasal 28 dari undang-undang tersebut, ditegaskan kembali bahwa pendidikan anak usia dini, diselenggarakan sebelum pendidikan dasar.

Hal ini berarti pendidikan anak usia dini (Paud), sebagai pintu awal memasuki pendidikan dasar, sehingga apabila di pintu awal anak sukses melewatinya, maka akan berdampak positif bagi pendidikan selanjutnya.

Dalam Permendiknas nomor 137 tahun 2014, dinyatakan bahwa guru Paud disyaratkan memiliki empat kompetensi, yaitu pedagogik, kepribadian, profesional, dan sosial. Salah satu kompetensi pedagogik yang perlu dimiliki guru paud, adalah kemampuan dalam mengembangkan potensi anak usia dini untuk pengaktualisasian diri melalui sarana kegiatan dan sumber belajar dan pembuatan media kegiatan.

Berkaitan dengan pentingnya pemanfaatan media dan sumber belajar, Masnipal (2013: 237) menyatakan: "Peranan media dan sumber belajar yang kaya dan beragam, sangat dibutuhkan anak usia dini untuk merangsang tumbuhnya kreativitas."

Hal senada disampaikan Badruzaman (2008:4.3), menyebutkan: "Peran media dalam komunikasi pembelajaran di taman kanak-kanak semakin penting, mengingat perkembangan anak pada saat itu berada pada masa konkrit." Heinich, dkk. (2002) dalam Instructional media and technology for learning menyatakan peran media dalam saluran komunikasi sebagai perantara antara sumber pesan (a source) dengan penerima pesan (a receiver).

Nana Sudjana

mengemukakan, bahwa sumber belajar adalah segala macam bahan yang dapat digunakan untuk memberikan informasi, atau berbagai keterampilan kepada murid dan guru. Segala macam bahan yang dimaksud, adalah semua bahan yang dapat digunakan, baik bahan-bahan yang berasal bahan-bahan bekas yang masih bisa dimanfaatkan untuk kepentingan pembelajaran bagi anak usia dini.

Bahan bekas adalah bahanbahan yang berasal dari barang-barang yang sudah tidak terpakai lagi, dan dapat didaur ulang kembali menjadi sesuatu yang bisa dimanfaatkan, seperti kertas bekas, koran, majalah, kardus, karton, kain, plastik, kaleng, styrofoam, busa, tali, tutup botol, sedotan, sendok es krim, botol plastik, keranjang buah dan karet. Hal itu bisa digunakan untuk media belajar yang aman, murah, dan ramah lingkungan.

Berkaitan dengan sumber belajar, Masnipal (2003) mengungkapkan bahwa sumber belajar dan alat peraga tidak harus membeli, guru kreatif dapat memanfaatkan lingkungan sekitar seperti daun, akar, batu, belalang, kepiting sawah, ulat, dapat menjadi sumber belajar yang menarik.

Untuk dapat memanfaatkan bahan bekas menjadi media dan sumber belajar, bagi anak usia dini dibutuhkan guru yang kreatif, memiliki keterampilan serta kemauan yang kuat untuk menciptakan proses pembelajaran yang menarik. Guru yang kreatif menurut Gautama (2011:4), “adalah guru yang tidak hanya pandai tetapi guru harus cerdas dalam mengembangkan keterampilan dan mencari bahan ajar yang betul-betul sesuai dengan peserta didik".

Berdasarkan pengamatan terhadap guru-guru RA Kecamatan 
Cipanas menunjukkan guru-guru RA belum kreatif dan memanfaatkan media bahan bekas kardus dan belum optimal melaksanakan media pengembangan bahan bekas kardus, sehingga berdampak kepada kurangnya partisipasi siswa dan proses pembelajaran.

Pelatihan pemanfaatan media bahan bekas kardus oleh instruktur dilaksanakan untuk menjawab tantangan dan kebutuhan guru dengan meningkatkan kreatifitas guru dalam membuat dan mengembangkan media bahan bekas kardus. Penulis bermaksud menguji Efektifitas Pelatihan Pemanfaatan Media Bahan Bekas Kardus Untuk Meningkatkan Kreatifitas Guru, Partisipasi Siswa dan Proses Pembelajaran di RA Kecamatan Cipanas Kabupaten Cianjur.

\section{Pembahasan}

Dibawah ini diuraikan temuantemuan penelitian yang diperoleh dari hasil analisis data, dalam temuan hasil penelitian ini dikemukakan secara berurutan berdasarkan urutan pertanyaan penelitian dalam rumusan masalah.

Sebelum dijelaskan lebih lanjut perlu dikemukakan bahwa tujuan penelitian ini untuk mengetahui gambaran tentang dampak pelatihan pemanfaatan bahan bekas kardus untuk peningkatan kreativitas guru, partisipasi siswa dan proses pembelajaran RA.

Penelitian ini mengangkat 4 pertanyaan dari rumusan masalah yang akan dicari jawabannya.

a. Apakah guru-guru RA memahami materi yang disampaikan pada waktu pelatihan pemanfaatan media bahan bekas kardus?

b. Apakah kreativitas guru RA lebih meningkat setelah mengikuti pelatihan pemanfaatan media bahan bekas kardus?

c. Apakah pelatihan pemanfaatan media bahan bekas kardus berdampak pada peningkatan partisipasi siswa?

d. Apakah pelatihan pemanfataan media bahan bekas kardus berdampak pada peningkatan proses pembelajaran?

Setelah dilakukan pengolahan dan analisis data diperoleh hasil penelitian sebagai berikut

a. Apakah guru-guru RA memahami materi yang disampaikan pada waktu pelatihan pemanfaatan media bahan bekas kardus?

Peneliti menggunakan 10 pertanyaan yaitu 1 s.d 10 yang ada pada kuisioner. Dari hasil kuisioner A pertanyaan 1 s.d 10 diatas hampir semua responden menjawab Ya dengan nilai ratarata diatas 0,5 artinya bahwa guru mampu atau memahami materi pelatihan pemanfaatan bahan bekas kardus.

Berdasarkan tabulasi data pada kuisioner A menunjukan bahwa guru RA telah memahami materi pelatihan media bahan bekas kardus pada saat pelatihan hal 50, ini diketahui sebanyak 0,70 atau $70 \%$ dengan pertanyaan 1-10 dari 50 peserta hanya 35 orang yang menjawab mampu, hal ini berarti bahwa sebagian besar guru memahami materi pelatihan pemanfaatan media bahan bekas kardus, untuk meningkatkan kreativitas guru.

b. Apakah kreativitas guru RA lebih meningkat setelah mengikuti pelatihan pemanfaatan media bahan bekas kardus?

Peneliti menggunakan 10 pertanyaan yaitu 11 s,d 20 yang ada pada kuisioner. Dari hasil kuisioner A pertanyaan 11 s.d 20 diatas hampir semua guru menjawab Ya dengan nilai ratarata diatas 0,5 , itu artinya bahwa adanya peningkatan guru setelah 
mengikuti pelatihan pemanfaatan media bahan bekas kardus.

Berdasarkan tabulasi data pada kuisioner A menunjukan bahwa pelatihan mampu meningkatkan kreativitas guru hal 53, ini diketahui sebanyak 0,64 atau $64 \%$ dengan pertanyaan $11-$ 20dari 50 peserta hanya 32 orang yang menjawab mampu, artinya sebagian besar guru mengalami peningkatan kreativitas mereka setelah mengikuti pelatihan pemanfaatan media bahan bekas kardus.

c. Apakah pelatihan pemanfaatan media bahan bekas kardus berdampak pada peningkatan partisipasi siswa?

Peneliti menggunakan 10 pertanyaan yaitu 1 s.d 10 yang ada pada kuisioner B. dari hasil kuisioner B pertanyaan 1 s.d 10 diatas hampir semua responden menjawab Ya dengan nilai ratarata diatas 0,5 itu artinya bahwa adanya dampak pelatihan pemanfaatan media bahan bekas kardus pada peningkatan partisipasi siswa.

Berdasarkan tabulasi data pada kuisioner $\mathrm{B}$ menunjukan bahwa peningkatan partisipasi siswa dalam pemanfaatan bahan bekas kardus hal 56, ini diketahui sebanyak 0,70 atau $70 \%$ dengan pertanyaan 1-10 dari 50 peserta hanya 35 orang yang menjawab mampu, artinya sebagian besar guru menyatakan terdapat peningkatan parisipasi siswa dalam pembelajaran setelah mereka mengikuti pelatihan pemanfaatan media bahan bekas kardus. d. Apakah pelatihan pemanfataan media bahan bekas kardus berdampak pada proses pembelajaran?

Peneliti menggunakan 10 pertanyaan yaitu 11 s.d 20 yang ada pada kuisioner B. Dari hasil kuesioner B pertanyaan 11 s.d 20 diatas hampir semua responden menjawab Ya dengan nilai ratarata diatas 0,5 itu artinya bahwa adanya dampak pelatihan pemanfaatan media bahan bekas kardus pada proses pembelajaran.

Berdasarkan tabulasi data pada kuesioner $\mathrm{B}$ menunjukan adanya peningkatan proses pembelajaran dalam pemanfaatan media bahan bekas kardus, hal 59, ini diketahui sebanyak 0,74 atau $74 \%$ dengan pertanyaan 11-20 dari 50 peserta hanya 37 orang yang menjawab mampu, artinya sebagian besar guru menyatakan mengalami peningkatan proses pembelajaran setelah mereka mengikuti pelatihan pemanfaatan media bahan bekas kardus.

Dari hasil kuesioner A dan B, diperoleh hasil penelitian sebagai berikut:

Dengan rumus,

$\frac{\text { rata-rata setiap butir }}{\text { jumlah pertanyaan }} X$ jumlah respoden $=$ $\ldots \%$

1. Berdasarkan tabulasi data pada koesioner A menunjukan bahwa guru RA telah memahami materi pelatihan media bahan bekas kardus pada saat pelatihan hal 50 , ini diketahui sebanyak 0,70 atau $70 \%$ dengan pertanyaan 110 dari 50 peserta hanya 35 orang yang menjawab mampu, hal ini berarti bahwa sebagian besar guru memahami materi pelatihan pemanfaatan media 
bahan bekas kardus, untuk meningkatkan kreativitas guru.

2. Berdasarkan tabulasi data pada kuesioner A menunjukan bahwa pelatihan mampu meningkatkan kreativitas guru hal 53, ini diketahui sebanyak 0,64 atau 64 $\%$ dengan pertanyaan 11-20 dari 50 peserta hanya 32 orang yang menjawab mampu, arttinya sebagian besar guru mengalami peningkatan kreativitas mereka setelah mengikuti pelatihan pemanfaatan media bahan bekas kardus.

3. Berdasarkan tabulasi data pada kuesioner B menunjukan bahwa peningkatan parstispasi siswa dalam pemanfaatan bahan bekas kardus hal 56, ini diketahui sebanyak 0,70 atau $70 \%$ dengan pertanyaan 1-10 dari 50 peserta hanya 35 orang yang menjawab mampu, artinya sebagian besar guru menyatakan terdapat peningkatan partisipasi siswa dalam pembelajaran setelah mereka mengikuti pelatihan pemanfaatan media bahan bekas kardus.

4. Berdasarkan tabulasi data pada kuesioner B menunjukan adanya peningkatan proses pembelajaran dalam pemanfaatan media bahan bekas kardus, hal 59, ini diketahui sebanyak 0,74 atau $74 \%$ dengan pertanyaan 11-20 dari 50 peserta hanya 37 orang yang menjawab mampu, artinya sebagian besar guru menyatakan mengalami peningkatan proses pembelajaran setelah mereka mengikuti pelatihan pemanfaatan media bahan bekas kardus.
Jawaban dari empat pertanyaan penelitian yang diajukan memberikan konstribusi untuk mengetahui gambaran tentang efektifitas pelatihan pemanfaatan bahan bekas kardus untuk peningkatan kreativitas guru RA Kecamatan Cipanas Cianjur.

Pertama, guru-guru yang mengikuti pelatihan pemanfaatan media bahan bekas kardus sangat memahami karena bahan bekas kardus patut untuk menjadi perhatian, terlebih untuk media pembelajaran, karena dari sisi ekonomi media bahan bekas kardus terbilang sangat murah dan mudah didapat, juga mendukung pengurangan sampah. Tabulasi hasil akhir perhitungan ratarata adalah 0,70 atau $70 \%$ dengan demikian dapat disimpulkan bahwa peserta atau guru mengalami peningkatan dalam pemanfaatan media bahan bekas kardus

Hal ini sejalah dengan pendapat Masnipal (2013:237) beberapa bahan bekas yang bisa digunakan sebagai media belajar yaitu: korang bekas, kertas semen, cangkang telur, biji kelengkeng dapat menjadi media pembelajaran.

Pemanfatan barang bekas adalah usaha atau aktivitas manusia untuk menggunakan benda atau barang yang sudah tidak terpakai lagi, untuk dijadikan barang baru yang memiliki nilai lebih tinggi, kurangnya pengetahuan serta pemahaman tentang pemanfaatan barang bekas oleh masyarakat, mengakibatkan timbulnya masalah yang sering dihadapi masyarakat yakni tumpukan sampah di lingkungan kita. (Yuliarti, 2010: 3)

Kedua, pelatihan mampu meningkatkan kreativitas guru, pelatihan sangat berpengaruh terhadap peningkatan kreativitas guru dimana guru menguasai pembelajaran, memunculkan ide-ide gagasan baru, berani mencoba dan menciptakan halhal baru, terampil dalam memilih alat peraga, gemar mencari hal-hal baru dan selalu berinovasi. Hal ini sejalan dengan 
tugas guru yaitu Permendiknas nomor 137 tahun 2014, dinyatakan bahwa guru Paud disyaratkan memiliki empat kompetensi, yaitu pedagogik, kepribadian, professional, dan sosial. Salah satu kompetensi pedagogik yang perlu dimiliki guru paud adalah kemampuan dalam mengembangkan potensi anak usia dini, untuk pengaktualisasian diri melalui sarana kegiatan dan sumber belajar dan pembuatan media kegiatan. Tabulasi hasil akhir perhitungan rata-rata adalah 0,64 atau $64 \%$ dengan demikian dapat disimpulkan bahwa peserta atau guru mengalami peningkatan kreativitas dalam pemanfaatan media bahan bekas kardus.

Ketiga, setelah mengikuti pelatihan ternyata mampu berdampak peningkatan pasrtisipasi siswa dalam pembelajaran hal ini guru-guru bisa menentukan langkah-langkah yang tepat dalam menetukan media pembelajaran dengan menggunakan media bahan bekas kardus. Dimulia dari persiapan pembelajaran, memilih/membedakan jenis-jenis bahan bekas kardus, membuat pola/merangkai pola, membimbing melengkapi pola, mendekorasikan kreativitasnya sampai menyajikan dan mengevalusinya. Tabulasi hasil akhir perhitungan ratarata adalah 0,70 atau $70 \%$ dengan demikian dapat disimpulkan bahwa ada peningkatan partisipasi siswa dalam pemanfaatan media bahan bekas kardus

Seperti halnya dari Bab dua halaman 47 Masnipal (2013) tentang tata cara dan langkah-langkah pembuatan media bahan bekas kardus.

Keempat, pelatihan pemanfaatan bahan bekas kardus sangat berpengaruh pada partisipasi siswa dalam pembelajaran. Tabulasi hasil akhir perhitungan rata-rata adalah 0,74 atau 74 $\%$ dengan demikian dapat disimpulkan bahwa adanya peningkatan proses pembelajaran dalam pemanfaatan media bahan bekas kardus. Hal ini sejalan dengan teori tentang kompetensi pedagogik guru kompetensi pedagogik merupakan kompetensi khas, yang akan membedakan guru dengan profesi lainnya. Penguasaan kompetensi pedagogik guru akan menentukan tingkat keberhasilan proses dan hasil pembelajaran peserta didik.

Cara atau metode pemanfaatan media bahan bekas kardus adalah salah satu cara paling tepat untuk mengembangkan kreativitas siswa (Masnipal, 2013:231).

\section{Metode Penelitian}

Metode yang digunakan dalam penelitian ini adalah metode deskripsi, yaitu metode penelitian yang menalar, menganalisa, mengklasifikasikan penyelidikan (Surachman 2000:56). Dalam penelitian ini secara teknis yaitu menakar, menganalisa, mengklasifikasikan penyelidikan tentang efektifitas pemanfaatan media bahan bekas kardus untuk penigkatan kreatifitas guru, partisipasi siswa, dan proses pembelajaran di RA Kecamatan Cipanas Kabupaten Cianjur.

Instrument yang digunakan dalam penelitian ini adalah wawancara kepada 5 (lima) orang guru yang telah mengikuti pelatihan dan telah melaksanakan pembelajaran dengan anak. Kuisioner / angket yang disebarkan kepada 50 (lima Puluh) orang guru-guru RA Kecamatan Cipanas Kabupaten Cianjur yang telah mengikuti pelatihan dan telah melaksanakan pembelajaran.

Teknik pengolahan data yang digunakan untuk mendesktifsikan hasil penelitian ini adalah teknik kategori atau rata-rata. Kuisoner menghasilkan data nominal akan tetapi dengan memberikan bobot jawaban yang diperoleh dari data rasio.

Untuk itu penulis tertarik dengan menggunakan rumus rata-rata / ketegori dalam analisis data. Adapun langkah- 
langkah yang ditempuh pengolahan dan analisis datanya adalah :

a. Membuat tabulasi data

b. Memberi bobot nilai $\mathrm{Ya}=1$ dan Tidak $=0$

c. Menjumlahkan bobot nilai sehingga diperoleh skor masing-masing butir

d. Mencari rata-rata dengan membagi jumlah nilai skor dengan jumlah responden

e. Kriteria kuesioner A dan B atau Ya dan Tidak, cara pengolehannya sebagai berikut.

Menentukan ya atau tidaknya jawaban dengan membandingkan rata-rata terhadap nilai 0,5 diperoleh dengan membagi 2 bobot jawaban $\mathrm{Ya}=1$ dan Tidak $=0$ atau $(1+0): 2=0,5$ kriteria yang digunakan

1. Jika nilai rata-rata $\geq 0,5$ maka dinyatakan ya, artinya mampu

2. Jika jika rata-rata $\leq 0,5$ maka dinyatakan tidak artinya tidak mampu/belum mampu

Langkah ini ditempuh untuk menyaring pendapat jika nilai ratarata setipa butir lebih dari atau sama dengan nilai pembatas 0,5 maka guru dinyatakan mampu memanfaatakan media bahan bekas kardus untuk peningkatan kreativitas guru RA Kecamatan Cipanas Cianjur, sebaliknya jika nilai ratarata kurang dari 0,5 maka guru dinyatakan kurang mampu memanfaatkan pemanfaatan media bahan bekas kardus.

\section{Kajian Pustaka}

Media dan sumber belajar
menjadi sangat penting ralam
mengembangkan pembelajaran efektif.
Media menurut Djamarah (1995:136)
adalah alat bantu apa saja yang dapat di
jadikan sebagai penyalur pesan guna
mencapai tujuan pembelajaran.
Selanjutnya ditegaskan oleh
Purnamawati dan Eldarni (2001:4)

media adalah segala sesuatu yang dapat digunakan untuk menyalurkan pesan dari pengirim ke penerima sehingga dapat merangsang pikiran, perasaan, perhatian dan minat siswa sedemikian rupa sehingga terjadi proses belajar.

Menurut Ardianto (2011:15) lingkungan yang ada disekitar anak kita merupakan salah satu sumber belajar yang dapat di optimalkan untuk pencapaian proses dan hasil pendidikan yang berkualitas. Hal menarik dari pendapat Ardianto bahwa lingkungan sebagai media pembelajaran yaitu bahan bekas karena mudah ditemukan di lingkungan sekitar. Lebih lanjut ia mencontohkan kardus bekas yang dapat dimanfaatkan untuk membuat kerangka rumah-rumahan .

Demikian juga menurut Masnipal (2013:237) beberapa bahan bekas yang bisa digunakan sebagai media belajar adalah Koran bekas, kardus, kertas semen, cangkang telur, biji kelengkeng, dapat menjadi media belajar. Rumondung dalam penelitiannya yang berjudul "Fiber Plastic Composible" dari bahan kardus dan Polyethylene (PE) dengan penambahan Malaet Anhidrida (MAH) dan Benzoil Perosida (BP) limbah kardus merupakan kardus atau Corrugated Paper merupakan bahan dasar kemasan yang memiliki daur hidup sangat singkat dan berharga ketika berlangsungnya proses distribusi produk dari produsen ke konsumen.

Pada kaitannya dengan manfaatnya dalam pembelajaran, dikutip dari jurnal disebutkan bahwa "To ensure the active participation of individuals, it is necessary to both foster their creativity and raise their awareness regarding the subject." Dilek Celikler dan Gonca Harman : 2015. Keduanya menjelaskan bahwa partisipasi siswa dalam penanggulangan bahan bekas dapat meningkatkan kesadaran dan rasa tanggung jawab pada lingkungan. 
Pendapat Celikler dan Harman dipertajam oleh ebook berjudul How To Reduce, Reuse And Recycle Waste In School 2007, didalamnya tertulis bahwa Schools have an important role to play in preparing and empowering students to take responsibility for creating and enjoying a sustainable future. Itu artinya sekolah menjadi sarana penting bagi siswa mengembangkan dirinya untuk mempersiapkan masa depan lebih baik salah satunya dengan meningkatkan rasa tanggung jawab mereka.

Dalam memanfaatkan media bahan bekas kardus ini dibutuhkan guru yang kreatif. Karena kreatifitas merupakan kemampuan menciptakan (Depdiknas, 2002 :599).

Menurut Munandar (1985) kretifitas adalah kemampuan untuk membuat kombinasi baru berdasarkan data informasi atau unsur-unsur yang ada. Hasil yang diciptakan tidak selalu harus baru, tapi juga dapat berupa gabungan (kombinasi) dari hal-hal yang sudah ada sebelumnya.

Rahmawanti Kurniati (2005:32) kondisi lingkungan sekitar anak sangat berpengaruh dalam menumbuh kembangkan kreatifitas.

Untuk dapat memanfaatkan bahan bekas menjadi media belajar dibutuhkan guru yang kreatif, memiliki keterampilan, dan kemauan kuat untuk menciptakan proses pembelajaran yang menarik. Masnipal (2013:237), supaya guru kreatif diperlukan pelatihan, karena pelatihan (training) adalah sebagai kegiatan mentransfer pengetahuan dan keterampilan kepada seseorang dalam kapasitas dirinya, ditempat kerjanya, atau tempat dirinya beraktifitas (A. Fauzi : 2011).

\section{Penutup}

Dari hasil penelitian sebagaimana diuraikan dalam bab IV dapat disimpulkan sebagai berikut:

1. Sebagian besar peserta pelatihan dapat memahami materi yang disampaikan dalam pelatihan pemanfaatan media bahan bekas untuk peningkatan kreativitas guru RA Kecamatan Cipanas Cianjur.

Secara khusus pemahaman materi pelatihan tersebut ditunjukan dalam:

a. Sebagian besar peserta atau guru, dapat mengenal pemanfaatan media bahan bekas kardus.

b. Sebagian besar peserta atau guru pelatihan atau guru, dapat menciptakan media bahan bekas kardus.

c. Sebagian besar peserta atau guru, dapat membedakan media bahan bekas kardus.

d. Sebagian besar peserta atau guru, dapat menggabungkan pemanfaatan media bahan bekas kardus.

e. Sebagian besar peserta atau guru dapat membuat langkah-langkah pembuatan media bahan bekas kardus.

2. Sebagian besar peserta pelatihan atau guru menyatakan terdapat peningkatan terhadap kreativitas mereka setelah mengikuti pelatihan pemanfaatan media bahan bekas kardus untuk pembuatan media pembelajaran, hal ini ditunjukan dalam:

a. Sebagian besar peserta atau guru menjadi banyak ide-ide atau gagasan baru.

b. Dalam pemanfaatan media bahan bekas kardus, semua peserta dapat menguasai pembelajaran.

c. Sebagian besar peserta atau guru menjadi lebih terampil.

d. Sebagian besar peserta atau guru dapat mencoba dengan hal-hal yang baru, dalam memanfaatkan media bahan bekas kardus.

e. Semua peserta atau guru dapat mengembangkan ide-ide

3. Sebagian besar guru menyatakan terdapat peningkatan terhadap 
partisipasi siswa dalam pembelajaran setelah mengikuti pelatihan pemanfaatan media bahan bekas kardus, hal ini ditunjukan:

a. Siswa dapat membuat pola media bahan bekas kardus.

b. Siswa dapat merangkai pola media bahan bekas kardus.

c. Siswa dapat memperaktekan media bahan bekas kardus.

d. Siswa dapat melengkapi media bahan bekas kardus.

e. Siswa dapat mendekorasikan media bahan bekas kardus.

4. Sebagian besar guru menyatakan mengalami peningkatan dalam proses pembelajaran, hal ini ditunjukan::

a. Proses pembelajaran dan siswa lebih termotivasi dalam pembelajaran media bahan bekas kardus.

b. Proses pembelajaran dan siswa menjadi lebih senang.

c. Proses pembelajaran dan siswa lebih tertarik.

d. Proses pembelajaran dan siswa lebih kondusif.

e. Proses pembelajaran dan siswa lebih aktif.

\section{Daftar Pustaka}

Andrianto, Dedy. 2011. Lingkungan Sekitar Sebagai Sumber Belajar Anak. Jakarta: Pustaka.

Badru Zaman 2008. Peran Media Dalam Komunikasi Pembelajaran. Yogyakarta: Pustaka Pelajar.

Depdiknas. 2003. Undang-undang RI Nomor 20 Tahun 2003, tentang sistem pendidikan nasional.

Dilek Celiker dan Gonca Harman. 2015. The Effect of SCAMPER technique in raising awareness regarding the collection and utilization of Solid Waste.
Journal of Education and Practice: 5 149-160

Dilek Çelikler dan Gonca Harman. 2015. The Effect of the SCAMPER Technique in Raising Awareness Regarding the Collection and Utilization of Solid WasteOndokuz Mayıs University, Faculty of Education, Science Education Program, Samsun, TURKEY. Journal of Education and Practice www.iiste.org ISSN 2222-1735 (Paper) ISSN 2222288X (Online)Vol.6, No.10, 2015

Gautama. O. 2011. Menjadi Guru Kreatif. Denpasar: Universitas Udayana.

Goerge, $\quad 2013$. Educational Technology as a Teaching and Learning Tool in Environmental Education. International Journal of Academic Research in Business and Social Sciences, 3 (9): 191205

Ikka Kartika A.Fauzi. 2011. Mengelola Pelatihan Partisipatif. Bandung: Alfabeta

M. Manullang. 2004. Dasar-dasar Manajemen. Yogyakarta: Gajah Mada University Press.

Masnipal. 2008. Model Pengembangan Kreativitas Melalui Permainan Konstruktif Dalam Proses Pendidikan Anak Usia Dini. Bandung.

Masnipal. 2013. Siap Menjadi Guru dan Pengelola PAUD Profesional. Jakarta: PT. Gramedia.

Munandar, $\quad$ S.C.U. 1985. Mengembangkan Bakat dan Kreativitas Anak Sekolah. Jakarta: Grasindo.

Nana Sudjana. 1995. Dasar-dasar Proses Belajar Mengajar. Jakarta: Sinar Baru Algesindo.

Permendiknas Nomor 137 Tahun 2014, tentang standar Nasional PAUD.

Purnamawati dan Eldarni. (2001). Media Pembelajaran. Jakarta. 
203 | Ai Aisah, Efektifitas Pelatihan Pemanfaatan Media Bahan Bekas Kardus Untuk Peningkatan Kreativitas Guru 